\title{
ROYAL JOSEON SOGYŎKSŎ AND PŎPCHO: THE PHILOSOPHICAL ENCUMBRANCE OF SARIM IN THE KIMYO LITERATI PURGE (1519) ${ }^{1}$
}

\author{
David W. Kim \\ Australian National University and Kookmin University
}

\begin{abstract}
The early modern history of the Joseon dynasty (1392-1910) in East Asia is often depicted as an era of political conflict between the king, the Hun'gu faction, and the Sarim faction. The four major Sahwa (literati purges) reflect its seriousness through which NeoConfucian scholars were sacrificed by the punishments of execution, exile, or dismissal. The Kimyo Sahwa was the most notorious incident for the Chinese ideology of the Sarim political party. What, then, happened in 1519 ? What kind of social transformation occurred in relation to the Sungkyunkwan scholars (the national university of the era)? Why did the public office of Daoist Sogyǒksŏ become one of the most controversial issues at the Joseon court? How was the royal shrine of Samch'óngjŏn criticised by the leaders of the Sarim faction? This paper explores the politico-religious landscape of early modern Korea through the key features of Jungjong coup (Royal Coup of 1506), Jo Gwangjo (1482-1520) and 'the Literati Purge of 1519', and argues the critical insight that the Daoist rituals and sacred sites (altars for the sky, stars, and gods) were traditionally maintained in the Pŏpcho philosophy of the royal sovereignty even if the culture of Jongmyo (ancestral altars) and Sajik (altars of soil and grain) were legally implemented at the beginning of the Confucian Joseon.
\end{abstract}

Keywords: Joseon History, Sarim faction, Literati Purge of 1519, Sogyŏksŏ, Korean Taoism

DOI: https//doi.org/10.3176/tr.2021.4.05

Received 6 July 2021, accepted 7 August 2021, printed and available online 10 December 2021

\footnotetext{
1 McCune-Reischauer Romanisation is generally applied but those personal names and places already generalised in the contemporary Korean society, are transliterated by the Revised Romanisation, including 'Joseon.' Surnames will be located before first names as it is normal in Korean culture. The dates of the royal records are based on the lunar calendar.

(C) 2021 Author. This is an Open Access article distributed under the terms and conditions of the Creative Commons Attribution-NonCommercial 4.0 International License (http://creativecommons.org/licenses/by-nc/4.0/).
} 


\section{Introduction}

Early modern East Asia commonly went through a domestic political transformation during the 15th and 16th centuries. The death of Yongle Emperor (永樂, 1360-1424) of the Ming dynasty (Han Chinese, 1368-1644) caused to lose the geopolitical influence in the region of Manchuria (northeast of China), as under control of the Mongols of the Northern Yuan dynasty (1368-1635) (Fisher 1988). Ashikaga Yoshimitsu (1358-1408) of the Ashikaga shogunate united the Northern and Southern Courts during the Muromachi period (1336-1573) of Feudal Japan, but the peace did not also last (Henshall 2012). When they lost the Ōnin War (応仁の乱, 1467-1477) to the daimyōs (大名, powerful Japanese magnates), the country was divided as hundreds of independent states. The chaotic Japan, further, encountered the emergence of the first Europeans (Portuguese) in 1543, who brought the musket, a muzzle-loaded long gun (Perez 1998).

The Joseon dynasty of Korea (1392-1910) was established by Yi Seong-gye (李成桂, 1335-1408) after Ming China (1368). ${ }^{2}$ Over the course of one hundred years, the Joseon court was transformed into four different factions of political philosophy. Chŏrŭip'a (節義派) was the group of officers who complained about the immoral conduct (leading a coup d'état) of the 7th king Sejo (世祖, 1455-1468) over the dethronement of the 6th king Danjong (端宗, 1452-1455). They dishonored the wicked Sejo, who had forced to exile, demote and poison his young powerless nephew king (less than fifteen years old) to Yeongwol (寧越, an Eastern mountain country). ${ }^{3}$ Ch'ŏngdamp'a (清談派) was another ideological group of literary people and poets who were strongly disappointed by the political decomposition of Sejo and his followers. They were not interested in obtaining public posts but organised a comrade party located nearby Dongdaemun (modern Seoul) (東大門 or Heunginjimun 興仁之門, Great East Gate) (Kim 2012: 155-201). ${ }^{4}$

2 His father was Yi Ja-chun (李子春: 1315-1361), an official of Korean ethnicity serving the Mongolled Yuan dynasty (1227-1368). The royal category of Kaeguk Kongsin (開國功臣, contributors of dynastic foundation merit subjects), for the establishment of the new dynasty, were divided into the three levels: Chwamyŏng Kaeguk Kongshin (佐命開國功臣, exclusive helpers of the one becoming the founding king: 20 people), Hyŏpch'an Kaeguk Kongshin (協贊開國功臣, sponsors of the one becoming the founding king: 13 people), and Iktae Kaeguk Kongshin (翊戴開國功臣, contributors of a meritorious deed: 22 people). See, 沈之伯 開國原從功臣錄券 (Certificate of Meritorious Subject Issued to Sim Ji-baek), written in 1397.

3 Sayukshin (死六臣, six martyred ministers) and Saengyukshin (生六臣, those royal officers giving up their government post) belonged to these people. Sayukshin (死六臣, six martyred ministers) were those executed by King Sejo for plotting to assassinate him and restore the former to the throne: Seong Sam-mun (成三問), Pak Paeng-nyeon (河緯地), Ha Wi-ji (河緯地), Yi Gae (李塏), Yu Eung-bu (俞應孚), and Yu Seong-won (柳誠源). Saengyukshin (生六臣) were those royal officers who still supported King Danjong (端宗, 1452-1455): Gim Siseup (金時習), Seong Damsu (成䎶壽), Won Ho (元吴), Yi Maengjeon (李孟專), Jo Rye (趙旅), and Gwon Jeol (權節).

4 As they regularly gathered at a bamboo grove, the elite group called themselves Chungnim Ch'irhyŏn (竹林七賢, Seven Sages of the Bamboo Grove). While avoiding secular honour, they enjoyed reading poetry, singing, and dancing (Nam Hyoon (南孝溫), Hong Yuson (洪裕孫), Yi Jeongeun (李貞恩), Yi Chong (李摠), and Hang Yeonggi (韓景琦)). The Yangban classes of scholars, writers, and musicians wrote the Daoist writings of Soyogŏn (逍遙巾, ritual writing). The classical scholars discussed the 
The Hun'gup'a (勳舊派, the meritorious elite party) $)^{5}$ were descendants of meritorious families who directly advocated the domination of Sejo's sovereignty and gained the political power in the Joseon court. During the regency process of Queen Jeonghui for her grandson King Seongjong (9th king, 13 years old), they became stronger and monopolised authority in politics. The possibility of marriages with royal families connoted the growth of their influence. ${ }^{6}$ They exploited various benefits of commerce (trade) and industry, while exhibiting a lack in or carelessness toward the philosophical dimension of Neo-Confucianism. ${ }^{7}$ Meanwhile, a new group appeared with the abstract ideology of morality and nationalism based on the Confucian teachings. The so-called Sarimp'a (士林派, the scholarly elite party) contained those who did not become involved in the establishment of the Joseon dynasty but continually countenanced the policy of the previous Goryeo dynasty (Jeong 2005: 7-62). ${ }^{8}$ They were the descendants of those people who dispersed to regions. ${ }^{9}$ The Sarim scholars had a chance to be public servants from the regency time of Queen Jeonghee (1469-1475) and the reign of King Seongjong (9th: 14761493) (Jeong 2005: 7-62). They were mainly employed at the three government watchdog organisations. ${ }^{10}$ The main roles of the public offices were to evaluate and indict government officials for corrupt or improper actions. They also played as official supervisors for the improper actions and policies of king and ministers (Wagner 1974: 20-27). ${ }^{11}$

teachings of ancient Chinese philosophers of Laozi (老子, 6th-4th century BCE) and Zhuang Zhou (莊子, 369-286 BCE).

5 or Gwanhakp'a (官學派).

6 The reorganisation of the policies of civilisation and institutions was one of the key achievements, along with the social application of practical learning. In particular, they participated in national publication projects of Kyŏngguktaejŏn (經國大典, the State Code or a Complete Code of Law), Tonggukyŏjisŭngnam (東國輿地勝覽, a Korean geography book), Tonggukt’onggam (東國通鑑, a chronical book of the early Korean history), and Tongmunsŏn (東文選, the anthology collected from the poetical works of late Three Kingdoms (18 BCE-935) and Goryeo dynasty (918-1392)).

7 Seo Geojeong (徐居正), Yi Geukdon (李克墩), Yi Seokyeong (李石亨), Han Myeonghoe (韓明澮), Shin Sukju (申叔舟), Gwol Lam (權掔), Jeong Inji (鄭麟趾), Jeong Changson (鄭昌孫), Choe Hang (崔恒), and Gu Chigwan (具致寬).

8 Jeong presumed that the Sarim scholars are often depicted as three different categories: scholarbureaucrats engaging in politics; rural scholars pursuing Confucian truth; and scholars accepting flexibly Daoist and Buddhist philosophy on the basis of Neo-Confucianism. In this paper the first category of the group is mainly explored.

9 The historical lineage is connected with Gil Jae (吉再, 1353-1419), a Goryeo scholar who studied under Yi Saek (李穡, 1328-1396) and Jeong Mong-ju (鄭夢周, 1338-1392). Gim Jongjik (金宗直, 1431-1492) and scholars of the Neo-Confucian school (Gim Sukja (金叔滋), Bae Ingyeong (雍仁 敬), Cho Eullyong (崔雲龍), and Gim Goengpil (金宏弼)) used to advocate maintaining the moral teachings of fidelity, justification, and integrity. The political asylum seekers gradually operated a self-management institute, called Yuhyangso (留鄉所: Local Government Advisory Committee), in order to watch out for immoral politico-cultural behaviour and conduct of the local authorities.

${ }^{10}$ The function of each government office will be detailed later (footnote 45) in this paper.

${ }^{11}$ They also professionally analysed Confucian philosophy and responded the king's questions by the custom of Kyŏngyŏn (經筵, lecturing the Confucian philosophy to king) while managing the royal library and research institute. 


\section{Political conflict and literati purges}

As they became the counterbalance of the royal court, the early modern Joseon experienced a socio-cultural transformation through a serious series of political purges between the two ideologically different parties of the Hun'gup'a (勳舊派, so-called 'the conservative group') and the Sarimp'a (士林派, 'the reformist group') (Kim 2020: 53-54). The reformative emergence of the Confucian scholars often threatened the traditional policy of the Meritorious Subjects (dominant Hun'gu party). The Sarim elites, through four major conflicts of the Yangban aristocracy, were thus brutally attacked and executed by the political plots of the Hun'gu people. Muo Sahwa (戊午士禍, Literati Purge of 1498) occurred when public servants of the Sarimp'a harshly complained about the polices of King Seongjong (9th: 1476-1493) and King Yeonsan-gun (10th: 1494-1506) based on the fundamental teachings of Neo-Confucianism. The unreliability issue of Gim Ilson's official writings and the misapprehension of Gim Jongjik (金宗直)'s Choǔijemun (中義帝文, a ritual writing for Emperor Yi of Chu of the late Qin dynasty (221-206 BCE) $)^{12}$ caused Gim Ilson (金麟孫, 1464-1498), Gwon Obok (權五福, 1467-1498), Gwon Gyeongyu (權景裕, ?-1498), Yi Mok (李牧, 1471-1498), and Heo Ban (許磐, ?-?) to be found the guilty of high treason and executed for their having slandered previous kings. ${ }^{13}$

Six years later, Kapcha Sahwa (甲子士禍, Literati Purge of 1504) was initiated yet again by King Yeonsan-gun; this time, however, misfortune fell on the side of senior Hun'gu politicians who were deeply involved in the process of dethroning Queen Yun Jeheon (1476-1479), the mother of Yeonsan-gun. Eom Gwiin (嚴貴人, ?-1504) and Jeong Gwiin (鄭貴人, ?-1504) were executed and their families were exiled and died there. When Yeonsan-gun tried to recover the honour of Yun Jeheon as Queen, the king also executed Gwon Dalsu (權達手, 1469-1504, the senior officer of the fourth court rank at Jiphyeonjeon (集賢殿, a royal research institute)) who disagreed with the king's intention. ${ }^{14}$ Ǔlsa Sahwa (乙巳士禍, Literati Purge of 1545) was about the power game of royal maternal relatives between the people of Queen Janggyeong (章敬王后, 1491-1515) and Queen Munjeong (文定王后, 1501-1565) (Um 2011: 107-115). Among the Sarimp'a, General Yun Im (尹任, 1487-1545), the older brother of Queen Janggyeong and Yun Won-hyeong (尹元衡, 1503-1565), the younger brother of Queen Munjeong, competed with each other at the royal court. Yun Im led the Daeyun groups (大尹) supporting the 12th king, Injong (仁宗, 15151545), but they were eventually defeated by Myeongjong, the 13th king, who was supported by Yun Won-hyeong's Soyun (小尹) group (Lee 2013: 37-62) (Annals of King Jungjong Vol. 85, October 27, 1537). How, then, was the most critical Kimyo

${ }^{12}$ The ritual writing of Gim Jongjik (金宗直, a leading founder of Samrimp'a, 1431-1492) was misinterpreted by the king over the actions of King Sejo (7th) to King Danjong (4th).

${ }^{13}$ Gang Gyeom (姜謙), Pyo Yeonmal (表沿沫), Hong Han (洪瀚), Jeong Yeochang (鄭汝昌), Gang Gyeongseo (姜景敍), Yi Sugong (李守恭), Jeong Huiryang (鄭希良), and Jeong Seungjo (鄭承祖) were sent off for banishment.

${ }^{14}$ Those who agreed the dethronement of Queen were also killed including Yun Pilsang (尹弨商), Yi Geukgyun (李克均), Gim Goengpil (金宏柘), Yi Sejwa (李世佐), Seong Jun (成俊), Gwon Ju (權住), and $\mathrm{Yi} \mathrm{Ju}$ (李胄). 
Sahwa (己卯士禍, Purge of 1519) incurred? Was it merely political or more intricate? How were the national traditions of Sogyŏksŏ (昭格署) and Samch'ŏngjŏn (三淸殿) embroiled in? What was the relationship of the royal family with Daoist philosophy? How was the religio-cultural landscape of Joseon between Pŏpcho (法祖) and Confucianism, between king and Sarimp'a, and between the Chinese teachings of Laozi (老子, Unknown, 6th-4th century BCE) and Confucius (孔子, 551-479 BCE)?

\section{Daoist Sogyŏksŏ versus Confucian moral ideology}

When Yeonsan-gun eliminated many classical scholars through the literati purges of 1498 and 1504, the 10th king started to lose public sentiment and politicians' sympathy. His dictatorial behaviour was demonstrated through such tyrannical policies as the abolition of Kyŏngyŏn (經筵, lecturing the Confucian philosophy to king), the implementation of Shinónp'ae (愼言牌, the card of waring in speaking before king), making a banquet place in Sungkyunkwan (成均館, the national (Confucian) university of the era), the demolition of private houses in the $12 \mathrm{~km}$ area of the palace, and the abrogation of Korean (Hangeul) books. At that time, the Hun'gu faction, under the leadership of Park Won-jong (朴元宗, 1467-1510), Seong Hui-ahn (成希顔, 1461-1513), Yoo Soon-jeong (柳順汀, 1459-1512) and Hong Gyeong-ju (洪景舟, ?-1521), aroused an anti-royal coup against Yeonsan-gun and successfully replaced Jungjong (中宗, 1488-1544) as the 11th king of Joseon in 1506. Since the throne was not naturally inherited, the new king, who was only 19 years old, was controlled by the Chŏngguk Kongshin (靖國功臣, Meritorious Contributors) of the Hun'gu faction. ${ }^{15}$

The powerless young king promptly appointed the opposite party of Sarim elites to make a political balance and promote the Wangdo Sasang (王道思想, a political philosophy of government which is based on the Confucian virtues). As they were employed at the three supervisory offices of 'Samsa' (三司, the Three Offices of the Royal Advice) ${ }^{16}$ the Sarim faction suggested various radical policies of large-scale reformation for the ideological society of morality (The Academy of Korean Studies 2020: 24-27, Kim 2003: 29-72). While most of the political issues were between the two factions for the power of the royal court, the abolition of Daoist Sogyŏksŏ (昭 格署) and Samch 'óngjŏn (三清殿) was a critical policy of the Sarimp'a to challenge the philosophical foundation of the king and royal family, who, based on the Pŏpcho teaching (法祖, the traditional ruling principles of forefathers in terms of filial duty), used to respect the harmony of heaven, king, and earth (citizens). In other words, the semicoercive compulsion of Jo Gwangjo (趙光祖, 1482-1520) symbolically implied that the religio-philosophical conflict between the royal tradition of Taoism and the Yangban thought of Neo-Confucianism anti-thetically co-existed in the early and middle era of the Joseon dynasty (Kim 2003: 29-72).

${ }^{15}$ Bag Wonjong (朴元宗), Seong Huian (成希顔), Ryu Sunjeong (柳順汀), Hong Gyeongju (洪景舟), Shin Yunmu (辛允武), Ryu Jagwang (柳子光), Bag Yeongmun (朴永文), and Jang Jeong (張珽).

${ }^{16}$ Sahŏnbu (the Office of Inspector General), Sagwanwŏn (the Office of Censors), and Hongmun'gwan (the Office of Special Advisors). 


\subsection{Taoism in Korea}

What is the origin of Taoism in Korean history? While the folk Taoism that reveres objects, places, and creatures such as animals, plants, rocks, rivers, weather systems, and human handiwork ${ }^{17}$ has existed for a long time, systematic Taoism was introduced in the Goguryeo kingdom (37 BCE-688 CE) in 624 to which Emperor Gaozu of Tang dynasty (618-907) sent a Daoist preacher and literature (道德经, Tao Te Ching) (Hwang 2015: 2-6). King Bojang (寶藏王, ?-682) and his minister Yeon Gaesomun (淵蓋蘇文, 594-665) transformed Buddhist temples into Daoist temples (Song 1986: 13-15, Seidel 1989: 295-300). The foreign religion of Taoism was popular in the court and the ruling class of the Goryeo dynasty (918-1392). King Yejong (r. 1105-1122) also invited two Chinese Daoshis (道士, master of the Tao) of the Northern Song dynasty (960-1126) and built the Daoist temple, called Bogwongwan (福源觀, the National Office of Taoism) (Yang and Choe 1988: 488489). ${ }^{18}$ The ritual for Noinseong (老人星, Canopus or $\alpha$ Carinae $^{19}$ ) was even performed at the royal house of King Uijong (毅宗, 1146-1170). Although Buddhism was the national religion for the Goryeo dynasty, the royal affection toward Taoism was resolute for the solid symbolism of sovereign power (Kim 2003: 29-72).

The Daoist tradition was transmitted into the culture and customs of the Joseon dynasty and royal families, even though another Chinese tendency, namely that of Neo-Confucianism, newly occupied the basic philosophy of the new Joseon court (Hwang 2015: 1-32). This caused an ideological confrontation between Laozi (老 子) and Chuang Tzu's (莊子, c. 369-c. 286 BCE) notions of balancing inner spirits and Confucius' (孔子) ideas of personal ethics and morality. For the purposes of national peace and royal wish-fulfilment, Yi Seonggye, the founding king of Joseon maintained Sogyŏkchŏn (昭格殿, Royal Temple of Taoism) to make official offerings to Laozi and the constellations in 1397 (Byun 1986: 4-12) (Annals of King Taejo Vol. 4, August 11, 1393). ${ }^{20}$ According to Chosŏn Wangjosillok (Annals of the Chosŏn Dynasty, 朝鮮王朝實錄), the king requisitioned 200 workers from the Dongdo (右道, the north side of the Han River) and Seodo (左道, the south side of the Han River)

${ }^{17}$ The concept of Daoism in this paper does not represent a folk religion with Korea's indigenous traditions of animism and shamanism, though shamans often include Daoist spirits among the supernatural beings they are interested in.

${ }^{18}$ The official places of Taech'ónggwan (大清觀, the official temple for worshipping Daode Tianzun (太清太上老君, Universal Lord of the Way and its Virtue, Laozi), Chŏngsasaek (淨事色, governmentrelated public office for the worship of Taoism), and Kuyodang (九曜堂, the altar for the worship of the eleven stars of Ch'iryo (七曜) and Sayo (四曜)) were also used as the residence of Daoists. Previous kings, such as Hyeonjong (1009-1031), Munjong (1046-1083), Seonjong (1083-1094), and Sukjong (1095-1105), had also placed Hoegyŏngjŏn (會慶殿, a Royal Daoist temple) in the T'agu field (打 求, a house riding game with a ball like polo) of the palace for Ch'ojae (醮祭), or Chaech'o (齋醮), the worship ritual of Daoist god, mainly T'aeilgugung (太一九宮, the god of Universal North Pole, symbolising the position of king in the universe).

19 The brightest star in the southern constellation of Carina is also known as the second-brightest star in the night sky.

20 甲申/幸廣明寺, 見王師自超, 遂幸昭格殿: King rapidly visited Gwangmyeong temple (廣明寺) for the affairs of King and then eventually visited Sogyŏkchŏn (昭格殿, Royal Temple of Taoism). 
of the nation (Annals of King Taejo Vol. 9, January 10, 1396). ${ }^{21}$ All the previous Ch'ojaesos (醮齋所 or Chaech'osos (齋醮所, the sacred sites of Daoist rituals and national ritual places)) were then integrated into Sogyŏksŏ (昭格署, Bureau of Brilliant Investigation) located at the north side of the Gyeongbok Palace (景福宮) during the reign of King Sejo in 1429 (You 2006: 130-135). ${ }^{22}$ The Sogyŏksŏ played the role of a government office in charge of Daoist rituals for the sky, earth, and stars:

When the Office of Protocol (禮曹) requested [to the king] that because Pyŏlchwa (別坐, the senior officer of the fifth (court) rank) for Sogyŏkchŏn (昭格殿, Royal Temple of Taoism) has many other responsibilities, he cannot focus on the sacred role efficiently, the king should select two diligent and trustworthy men from Chŏnham (前銜, formal public officers) and Munshin (文臣, those who pass the civil service literary examinations) for the position. It was then carried on (禮曹啓: 昭格殿別坐以他官兼任, 不得 常仕殿內, 諸事虛疎。請自今別坐二員涉擇前銜文臣勤謹者差之, 使專其任, ... 從之) (Annals of King Sejo Vol. 18, November 28, 1459).

\subsection{Sacred sites and rituals}

There were four temples, such as Samch'ŏngjŏn (三清殿), T'aeilchŏn (太一殿), Chiksujŏn (直宿殿), and Shibiryojŏn (十一曜殿) (Lee 2000). ${ }^{23}$ Among them, the sacred site of T'aeilchŏn (太一殿, the temple for the god of Polaris (or the North Star)) was for the prevention of and protection from fatal diseases of heaven and earth, fire and calamity, and life and death (Ahn 2004: 11-14). ${ }^{24}$ The female divine image of Ch'ilsóngjesu (七星諸宿, for the Big Dipper) was enshrined in the temple, even though Ahn interpreted the Big Dipper as the symbol of the King of Heaven (Ahn 2004: 15-37, Jung 2015: 242-276). ${ }^{25}$ The male divine figures of Yuanshi Tianzun (玉 清元始天尊, Universal Lord of the Primordial Beginning; Jade Emperor), Lingbao Tianzun (上清靈寶道君, Universal Lord of the Numinous Treasure), and Daode Tianzun (太清太上老君, Universal Lord of the Way and its Virtue: Laozi) (Song 1986: 14-18) were placed at the Samch'ongijon (三清殿, the temple for the highest deities of Taoism) (Yun 2003: 56-82). ${ }^{26}$ Chiksujŏn (直宿殿) was the temple for the

21 'For the establishment of Sogyŏkchŏn (昭格殿, Royal Temple of Taoism), the people were requisitioned from Dongdo (右道, the north side of the Han River) and Seodo (左道, the south side of the Han River) of the nation (已巳/發左右道丁二百, 營昭格殿).'

${ }^{22}$ Those Daoist temples which used to be in the palaces of Goryeo dynasty (918-1392) were Pogwŏn'gwan (福源觀), Shin'gyŏkchŏn (神格殿), Kuyodang (九曜堂), Sojŏnsaek (燒錢色), Taech'ŏnggwan (大淸觀), and Ch’ŏnggye Baesŏngso (淸溪拜星所).

${ }^{23}$ T'aeilchŏn (太一殿) was relocated in 1471.

${ }^{24}$ There were three T'aeilchŏns (太一殿) at Hwaryeong (和寧), Chungju (忠州), Bupyeong (富平), and Gwiju (龜州), but by a royal order they were united later in Joseon era.

${ }^{25}$ It indicated Okwang Sangje (玉皇上帝, Jade Emperor).

${ }^{26}$ There were ten spirit tablets including of Yuanshi Tianzun (玉皇上帝, Jade Emperor), Daode Tianzun (太上老君, Laozi), Lingbao Tianzun (普化天尊), and Chaedongjegun (梓潼帝君, the god for people's happiness and intelligence). See 新增東國舆地勝覽 (An Official Book of Geography), edited in edited in 1481,1486 , and 1530 . 
nine stars related to the accession of the king and fate of people ( Ju 2020), ${ }^{27}$ while Shibiryojŏn (十一曜殿) worshiped the eleven stars of Ch'iryo (七曜, the seven unique stars) and Sayo (四曜, the four unique stars or dark and invisible cases of stars) (National Museum of Korea 2020). ${ }^{28}$ The spirit tablets of Sahae Yongwang (四 海龍王, the four kings of the East, West, South, and North sea), Myŏngbu Shibwang (冥府十王, ten kings of judging dead people), and Subu (水府, its assistants) were additionally enshrined at the internal and external altars of Sogyŏksŏ (昭格署) (Lee 1986: 32-34, Kim 2003: 29-72, Yun 2003: 45-52; Annals of King Jungjong Vol. 26, November 21, 1516). ${ }^{29}$

The national organisation was operated by public servants such as Chejo (提調, the junior grade of the fifth (court) rank; 1 person), Pyŏlche (別提, the senior grade of the sixth (court) rank; 2 people), Ch'ambong (參奉, the junior grade of the ninth (court) rank; 2 people), and Chapchik (雜職, technical officer; 15 people ${ }^{30}$ ) (Annals of King Jungjong Volume 9, August 28, 1509.). Daoshi (道士, male Daoist priest) was also given the public position through a national examination as the grade of the fourth (court) rank (You 2006: 141-153). The official rituals of Ch'ojae (醮齋, or Chaech'o 齋醮, the sacred ritual of Taoism) were performed by either Daoshi or Yŏgwan (女冠, female Daoist priest) (Yun 2003: 45-82). ${ }^{31}$ The Daoist principle of gender equality opposes the masculine centred society of Confucianism, in which the teaching of Namjonyobbi (男尊女卑, man is noble, and woman is lowly) looked down on women in the Joseon dynasty (Chae 2019: 192-201).

The general purpose of the rituals include national security and prosperity, blessing and longevity of the king and royal family, guidance of ancestors and dead people into the immortal world, prosperity of descendants, prevention from calamities and climate change, and welfare of the public (Kang 2009: 322-327, You 2006: 135-137, Jung 2015: 242-276). The Annals of King Jungjong (中宗實錄) mentions that many miracles occurred for the nation as worshipping stars of the sky at the Sogyŏksŏ (昭格 署): "the king also claimed that one should not neglect to hold the rituals for stars at the Sogyŏksŏ, for many marvellous things previously occurred (上又問日: 昭格殿醮星之 事, 靈異屢著, 不可忽也)" (Annals of King Jeongjong Vol. 6, December 18, 1400). In particular, for the lifespan of the king and royal family, the ritual of Songshinch'ojae

${ }^{27}$ The nine stars for the fortune of men are called Nahujiksŏng (羅睺直星, overlapped phenomenon of Sun and Moon), T'ojiksŏng (土直星, Saturn), Sujiksŏng (水直星, Mercury), Kŭmjiksŏng (金直 星, Venus), Ilchiksŏng (日直星, Sun), Hwajiksŏng (火直星, Mars), Kyedojiksŏng (計都直星, comet), Wŏlchiksŏng (月直星, Moon), and Mokchiksŏng (木直星, Jupiter).

${ }^{28}$ The Ch'iryo includes Sun, Moon, Venus, Mars, Jupiter, Mercury, and Saturn. The Sayo are Kyedo (計 都, lunar eclipse), Nahu (羅睺, solar eclipse), Wŏlp'ae (月孛, origin point of moon's path), and Chagi (紫氣, an imaginary star circulating the sky every twenty eight years).

${ }^{29}$ As well as 360 holy men and 3600 holy stars. 'the Sogyŏksŏ (昭格署)... holds a ritual for Laozi and stars. For the worship of Laozi... (昭格署, … 而只祭星辰、老子祭, 老子, …'.

${ }^{30}$ There were the various positions of Sangdo (商道, the 8th official rank of the government for Taoism ritual), Chido (志道, similar public position with Sangdo), Toryu (道流, public position for rituals), Saengdo (生徒, public position for rituals), and Ch'wijae (取才, another assistant position involving the rituals).

${ }^{31}$ Daoshi was the figure who pursues to be a supernatural sage of the world through a strict regulation of self-cultivation. S/he was presumed to have a spiritual ability of communicating with gods. 

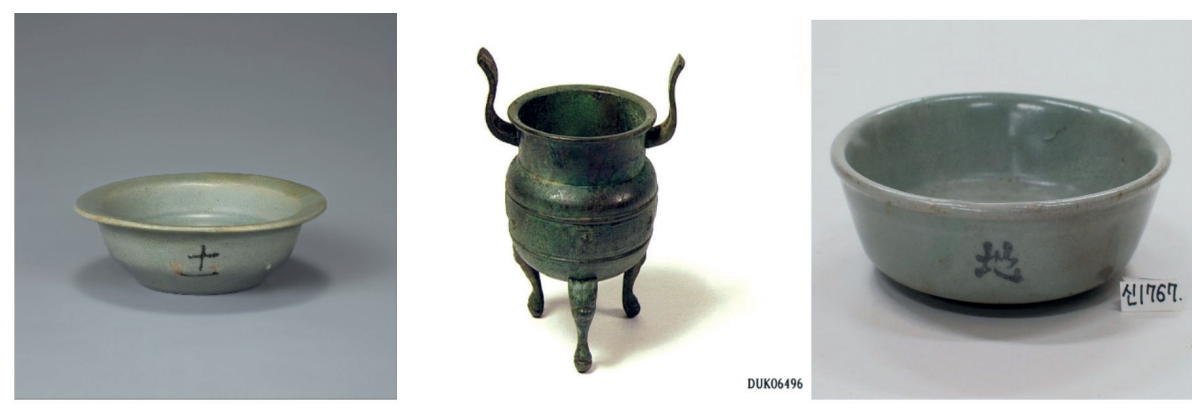

Figure 1. Utensils used for Daoist rituals. (C) National Museum of Korea.

(星辰醮祭, the ritual for the gods of stars) was conducted in the names of Songsuch'o (星宿醮, the ritual for the god of Leo) (Jung 2015: 235-276), Puktuch'o (北斗醮, the ritual for the god of Big Dipper), Kŭmsŏngch'o (金星醮, the ritual for the god of Venus), T'aeŭmch'o (太陰醮, the ritual for the god of Luna), Chinmuch'o (眞 武醮, the ritual for the spirit of Baekje's patriotic nobleman), Chiksŏngch'o (直星 醮, the ritual for the god of the 'destiny star'), and Hyŏnghokkich'o (熒惑祈醮, the ritual for the god of Mars) (Jung 2015: 235-276, Kim 2008: 284-294; Annals of King Seongjong Vol. 77, February 18, 1477). ${ }^{32}$ Kings Taejo (1398), Taejong (1403), and Sejong (1420) held the Daoist ritual of Kaebokshinch'o (開福神醮, for the blessing of king's descendants). The national rituals of Ch'óngmyŏngch'o (請命醮, the ritual of the previous king for present king), Tobyŏngch'o (禱病醮, the ritual for the sickness of the queen), and Kiuch'o (祈雨醮, the ritual for drought and rain ${ }^{33}$ ) (Annals of King Sejo Vol. 12, May 12, 1458), like the ancient harvest ceremony, largely involved musical performances (Kim 2008: 284-294). ${ }^{34}$

${ }^{32}$ For the rituals, the Daoist priest, the Daoshi, puts a Soyogwan (逍遙冠, a unique ritual hat) on his head and wears the scroddled black clothes. A Hol (笏, a ritual tablet) is held on the ceremonial dress. The ritual was composed of incense, flowers, candlelight, and ritual bowls and dishes. The public servants of Daoist rituals presented fruits, rice cakes, tea, soup, etc. When they rang the bell 24 times, two priests read the Tojang (道藏, Daoist canon, consisting of around 1,400 texts including Yŏnsaenggyŏng text (延生經), T’aeilgyŏng text (太一經), Okch’ugyŏng text (玉樞經), Chinmugyŏng text (眞武經), and Yongwanggyŏng text (龍王經). They wrote Ch'uksa (祝辭, thoughtful letter to gods) on blue paper and burnt it off in prayer of wish. They then offered kowtow one hundred times according to the T'aeilch'oryemun (太一醮禮文) of Tonggugisanggukchip (東國李相國集, one of the books which mention the founding myth of Goguryeo written in 1241). 韓明澮 沈澮曹錫文金礩徐居 正議 太一殿 自乾方移艮方 自艮方移巽方 我國無定方位文籍 於中朝亦未得聞 臣等以爲今移坤方 坤方最 宜先定 令觀象監定方所後祭儀一依義城例施行.

33 'It is not necessary to worship heaven as being performed at the Sogyŏksŏ already. If there is no rain, report it later (湼禱于昭格殿, 不必祀天也。如不得雨, 更啓)'.

${ }^{34}$ As well as Chinbyŏngch'o (鎭兵醮), Samwŏnch’o (三元醮), Samgyech’o (三界醮), and Sogyŏkchŏn Bonmyŏngch'oje (昭格殿本明醮祭). Each Ch'ojae (ritual) used different canonical texts, such as the T'aeilgyŏng text (太一經) for Samch'ŏngch'ojae and T'aeilch'ojae, the Yŏnsaenggyŏng text (延生經) for Sŏngshinch'ojae, and the Yongwanggyŏng text (龍王經) for Giuch'ojae. 


\subsection{Sogyŏksŏ and political debate}

Byung Rae You presumes that the Joseon Sogyŏksŏ (昭格署, Bureau of Brilliant Investigation) and Samch'ŏngjŏn (三淸殿, the Daoist temple for the highest deities of Taoism) would have been in different locations of a similar region overlooking Gyeongbokgung Palace (景福宮). The Sogyŏksŏ would have been on the East hill of the current residence (Samch'ŏngdong) of the prime minister. Here, Samch'ŏngjŏn would have functioned as the mental pillar of the king and Joseon dynasty (You 2007: 232-235). The Gwaui Taoism (科儀道敉, Ritual Taoism) of the Joseon dynasty was unable to be formed as a professional organisation; rather, it was conceived as national offering rituals to heaven by the Head of State (Ch'a 1986: 46-54, Byun 1986: 8-12). For the Confucian literati, it was seen as a folk religion "which served as an innately religious function and concurrently as a source of salvation among common people" (Kang 2009: 321-324, Hur 2020: 233-242). On the other hand, such Daoist rituals cooperated within the principles of Pŏpcho (法祖), the supreme role of the king and royal family, in terms of mediating between heaven and citizens for the development and prosperity of Joseon.

Figure 2 depicts the sun, moon, and nature, which used to represent the presence of the king. As such, the Daoist Royal Folding Screen was mainly located behind the throne in the royal court of each palace: Geunjeongjeon (勤政殿, the court of law), Injeongjeon (仁政殿, the court for diplomacy, where vassals came to pay their respects and royal events were held), Myeongjeongjeon (明政殿, the court of Changgyeonggung Palace), Sungjeongjeon (崇政殿, the court for proclaiming political order or legislation and receiving respect from vassals), and Junghwajeon (中和殿, the court for receiving New Year greetings and national events). The Irworrobongdo (日月五峯圖), which are composed of five mountain peaks, pine trees, and water streams, was believed to have been objects provided by heaven to protect the king. The symbols of the sun (for king) and moon (queen) reflected the practical method for the virtue of the king. Whenever the king attended various royal or national events, the Daoist Royal Folding Screen was likewise installed behind his temporary throne, connoting his sacred role as a mediator between heaven and earth (citizens) (Irworrobongdo 2021).

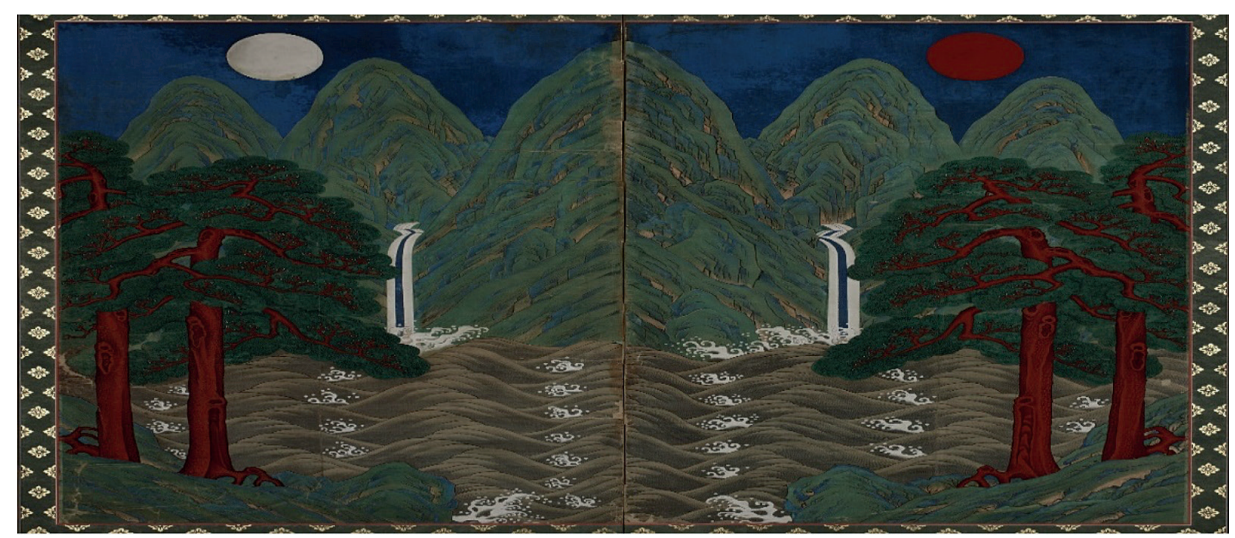

Figure 2. Irworrobongdo (the Daoist Folding Screen for King). (C) National Museum of Korea. 
According to the classic novels of Imhwajŏngyŏn (林花鄭延) and Sonch'ŏnsayŏngirok (孫天師靈異錄) (Chae 2019: 125-227), the royal culture of Taoism was transmitted from the Chinese tradition in which emperors build Daoist temples and immortals. The celestial masters worked for the Imperial House. Nevertheless, the royal behaviour was against the basic principle of Confucianism in which the political philosophy of Joseon's Sarim faction was established. They rather wanted their king to respect the ancestral traditions of Jongmyo (宗廟, a Confucian shrine for the deceased kings and queens) and Sajik (社稷, national altars of soil and grain (millet)). In the Confucian thought the Chinese emperor was only allowed to worship heaven. The king of Joseon was not qualified to do so as a feudal lord: "the Sogyŏksŏ is the sacred place to hold a ritual for the stars. As [the Chinese] Emperor can worship heaven, feudal lords [including Joseon king] should only hold a ritual for mountains and streams only. Therefore, it is not right for the traditional manners (則昭格署, 乃祀星辰矣。天子然後祭天, 諸(后)〔侯〕只祀山川, 而至於祀天, 殊非合 禮, 革之爲當)" (Annals of King Jungjong Vol. 13, May 12, 1511). The royal Daoist Sogyŏksŏ was the major political encumbrance of Confucian scholars, but it was directly related to the custom and authority of the king and royal families in the political legitimacy of the Joseon Pŏpcho (法祖).

The philosophical issue was the major controversy of the royal court at the time of King Yeonsan-gun. When the political power of the Sarim faction, as mentioned by Hur Joon (Hur 2020: 237-238), became predominant through the successful appeal regarding rehabilitating the status of Queen Dangyeong (端敬王后, 14871557) and related events (1515), King Jungjong (中宗, 1488-1544) was pressured to abolish the Daoist office of Sogyǒksŏ and Samch'öngjŏn in 1518 (Kim 2003: 2972). The repressive policy on Buddhism (抑佛政策) diffused into the royal culture of Taoism as well. King Jungjong, who ruled for 39 years, initially carried on the royal tradition of heavenly spirituality. The Daoist office in the place of Prince Yi Hang (李㤖) was regularly repaired (Annals of King Jungjong Vol. 1, October 27, 1506). ${ }^{35}$ Nonetheless, The Annals of King Jungjong (中宗實錄) proves that the cultural and political conflict of Sogyǒksŏ occurred 203 times in the 1510s.

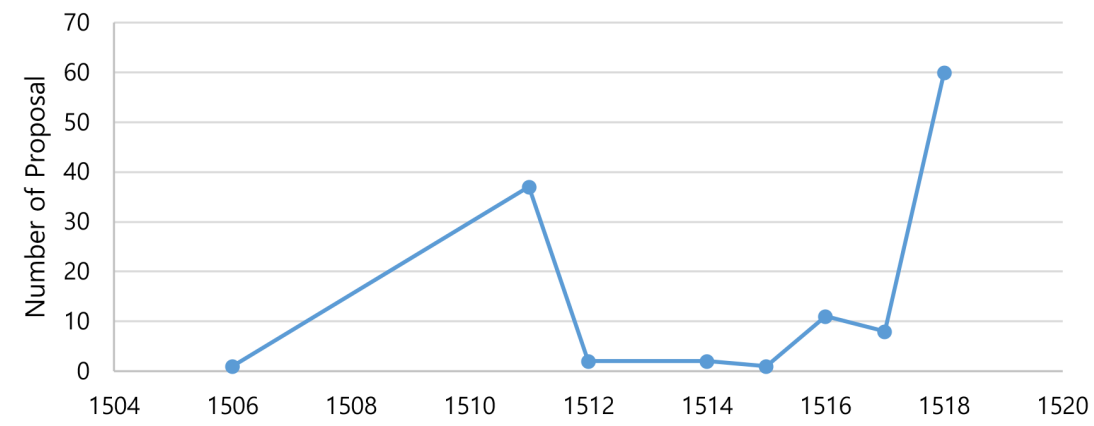

Figure 3. Royal court issue of Sogyŏksŏ during King Jungjong's reign (1506-1544). ${ }^{36}$

35 “傳于工曹日: 急修昭格署, 令本署官員還入.

${ }^{36}$ The date is collected based on the information from The Annals of King Jungjong between 1506 and 1519. 
Figure 3 demonstrates that the proposal number of the Sogyŏksŏ agenda rapidly increased in 1511. In particular, between May and August, 37 of 131 proposals were intensively submitted to the royal court by Confucian scholars (including those working at the Samsa (三司, the Three Offices of the Royal Advice)) for the abolition of the Daoist ritual. ${ }^{37}$ Jo Sun (趙舜, 1465-1527) from Hongmun'gwan (弘文館, the Office of Special Advisors) argued about the costs of its rituals and maintenance: “Sogyǒksŏ was a cultic religion out of Confucian teachings and it costs a lot (昭格署, 左道祈禳, 耗用不貲, 慢天瀆神, 莫此爲甚)” (Annals of King Jungjong Vol. 13, May 4, 1511.). The unnecessity of worshiping gods of heaven was another reason: "feel empty that our Sogyŏksŏ worships the gods of heaven (我國昭格署, 亦祀天神, 至爲虛誕)” (Annals of King Jungjong Vol. 13, May 15, 1511). The veneration of Chibushiwang (地府十王, ten kings of the dark world (or hell) or Myŏngbushiwang (冥府十王, the ten kings of judging dead people)) was also denounced, as if worshiping of Laozi (Annals of King Jungjong Vol. 21, February 21, 1515). ${ }^{38}$ However, King Jungjong refused their suggestion due the late kings having maintained the convention for a long time and that the tradition was recorded in the Kyŏngguktaejŏn (經國大典, a Completed Book of all Joseon Laws, Customs and Decrees): "For the Sogyŏksŏ is written in the Kyŏngguktaejŏn, we cannot easily change the traditional law of the royal (昭格署, 則載在《大典》, 祖宗舊章, 不可輕革)” (Annals of King Jungjong Vol. 13, May 10, 1511). Hur Joon additionally presumed the relation with the social trends of the 'disorder the government organization,' 'weakening national defence,' 'unfairness in engagement of talent,' 'impoverishment of public welfare,' and 'indolence of vassals' (Hur 2020: 253-254).

Thereafter, it was quiet for four years, but appeals regarding the destruction of Sogyŏksŏ were frequently proposed to the royal court between 1516 (eleven times) to 1517 (eight times). When the political position of the Sarimp'a dominated the royal court in $1518,{ }^{39}$ King Jungjong received sixty appeals in six months between April and September. The removal issue of Sogyŏksŏ was politicised almost every three days before the king. Sung Hwan Kim argued that Jo Gwang-jo penetrated the dilemma of the king (Kim 2003: 54-72, Lee 2010: 315-339). The condition of Sogyŏksŏ was gradually recognised as a cult, but the royal family aspired to keep the long-term tradition of the Laozi belief. Confucian scholars aimed to replace the Daoist thinking with the moral teachings of Confucius (551?-479 BCE). The students of Sungkyunkwan (成均館) also involved the anti-Confucian policy of Sogyŏksŏ (成均館生員權磌等上疏, 請革昭格署, ...) (Annals of King Jungjong Vol. 34, August 27, 1518). Jeong Gwangpil (鄭光倨, 1462-1538, the Chief State Councillor), Sin Yonggae (申用溉, 1463-1519, the Second State Councillor), and An Dang (安瑭,

${ }^{37}$ Sahŏnbu (司憲府, the Office of Inspector General), Sagwanwŏn (司諫院, the Office of Censors), and Hongmun'gwan (弘文館, the Office of Special Advisors) as well as Taesahŏn (大司憲, the head of the Sahŏnbu (司憲府, the Office of Inspector General) and Taesagan (大司諫, the third rank of the government).

${ }^{38}$ The Daoist gods (Chibushiwang) is also found in Buddhist temple nowadays. 聽輪對。豐儲倉主簿盧 敦日: 昭格署醮祭, 佛家所謂地府十王亦與焉, 荒怪尤甚.

${ }^{39}$ He passed the national examination for Sungkyunkwan (成均館) in 1510. When he was thirty-four years old, he stated to gain the public position from 1515 . 
1460-1521, the Third State Councillor) also supported them but were rejected by

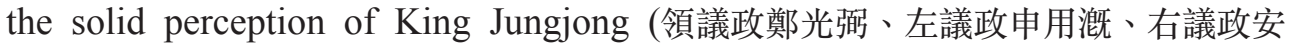
瑭等, 以昭格署事三啓, 不允) (Annals of King Jungjong Vol. 34, August 29, 1518). The petition of Yeo Youngha and Yusaengs (儒生, Confucianists) was continuously presented to the king:

Laozi found Taoism as a religion and thereafter, many innocent and gullible ordinary people were blinded to its false truth and bedevilled into believing in the efficacy of its practices and truth. The Daoist practices and its truth are absolutely preposterous and absurd... Historically, because of the falsity and untruthfulness, Taoism has been suppressed and barred by preceding dynasties. Now the king's attitude toward Taoism appears to be improper (Kang 2009: 329).

The consistent political pressure eventually led to the closure of the government office in charge of Daoist rituals for the sky, earth and stars on September 3, 1518 (Annals of King Jungjong Vol. 34, September 3, 1518; the Academy of Korean Studies 2000: 45-51). Kang interpreted the chaotic situation of the Joseon court to mean that "the literati or Confucian scholars [only] aspired to serve the dual functions of Neo-Confucianism: the socio-ethical and religious functions" (Kang 2009: 344). As the Daoist institution on the national stage ebbed away, Confucian intellectuals' committed adherence to their own truths got rid of all the ideological oppositions (Kang 2009: 327-331).

\subsection{Kimyo controversies (1519)}

It was not the end of the controversy. ${ }^{40}$ The Sarimp'a used to take interest in the practical issues of the Joseon society (for example, Hyangyak, 鄉約, regional autonomism regulation or a self-governing system of community) of ordinary people's lives (Lee 2010: 7-36, Hur 2020: 254-258). However, the gradual involvement of serious politics and new policies of ideological reformation challenged the position of the king, who wished to keep the philosophical principles of Pŏpcho (法祖). Jaeyun Mun interpreted the meaning as 'mental assets' in the aspect of "Chosangŭi arŭmdaun ttŭtkwa haengjŏkŭl ponbadayahanda [Descendants (current sovereign) should emulate the beautiful intention and achievements of (royal) forefathers]" (Mun 2009: 343). He then developed four key points out of the royal thought: 1) king should respect the heavens; 2) king should model ancestors; 3) king should love citizens; and 4) king should raise genuine vassals. Among them, the attitude of modelling ancestors was argued as the most significant idea the king preferentially considers (Mun 2009: 347). In that way, the Daoist rituals of Sogyŏksŏ were part of following the Pŏpcho legitimacy as the royal tradition. Herein, Song maintains that

${ }^{40}$ Most contemporary scholars mainly approach the incident of the Kimyo Literati Purge (1519) within the political conflict between the two factions. The religio-historical issue of royal Daoist Sogyŏksŏ from a traditional perceptive of king is less regarded. 
King Jungjong did not give up his wish to kill Jo Kwangjo (趙光祖, 1482-1519), who was the key leader of the Sarimp'a (Song 2005: 70-120). The young reformists additionally enforced the new system of Hyŏllyanggwa (賢良科, public recruitment system performed by king's personal interview). ${ }^{41}$ It was when the (Confucian) elites with virtue, talents, and skills were recommended the king personally had to interview and appoint them for a public position. As a result, there were 123 politicians from the Sarimp'a group during the Jungjong reign (Park 1998: 77-79). ${ }^{42}$

Lee argues that Jo "was the moralist who had the purest conscience and aimed the devoted politics among many fellow Confucianists of the Joseon dynasty" (Lee 2010: 36). However, the intimidatory revision of Chongkukgongsin (靖國功臣, the list of recognised contributors for the royal coup) caused the alternative political debate against the Hun'gup'a (勳舊派), who had led the royal coup of 1506, by which Jungjong became the eleventh king of Joseon (The Academy of Korean Studies 2000: 62-73, Hur 2020: 254-258). There were 117 meritorious contributors recognised by the government. Jo, under the support of Sungkyunkwan (成均館) students, ${ }^{43}$ argued for the unmeritorious cases as well as the immoderate benefits of political and financial fortune (Wagner 1974: 28-142, Jeong 2005: 7-62, Chung 1995: 87-112, Kim 2018: 48-56)):

Jo Kwangjo proposed [to the king] that the announcement of Chongkukgongsin (靖國功臣, the list of recognised contributors for the royal coup) has been ten years, but many of them are false beneficiaries. As Seong Huian (成希顔, 1461-1513) is mediocre without unique skills, there is not much to compliment. Bag Wonjong (朴元宗, 1467-1510) already died on duty. These people did not do [any prize-worthy work], but I was presumptuous because Yu Jagwang (柳子光, 1439-1512) himself recorded the details of Chongkukgongsin (趙光祖日: 靖國功臣, 已至十年之久, 事多虛 縀。成希顔, 不甚庸者, 而其器不遠大。雖有大功, 其人不足向也。朴元宗, 純直人 也。此等人則不爲如此也, 功臣磨鍊, 柳子光, 專主爲之, 故至此濫也) (Annals of King Jungjong Vol. 37, October 25, 1519).

King Junjong had to permit the revision of the details that brought the wrath of the Hun'gu leaders, such as Sim Jeong (沈貞, 1471-1531), Nam Gon (南䘚, 1471-1527), and Hong Gyeongju (洪景舟, ?-1521). As a result, the king ordered the execution of Jo and his political colleagues during the night without a proper legal procedure of punishment (Jin 2009: 36-42). ${ }^{44}$ The religio-political pressure of the

${ }^{41}$ For the new public recruitment system, potential candidates, who have excellent skills and abilities, were recommended for a personal interview with the king.

42 The innovation of political elite recruitment is often interpreted as a benefit of the king to have a political balance between two political parties, for the two previous Sahwa (士禍, literati purges) in 1498 and 1504 had brought a major sacrifice.

${ }^{43}$ When Jo was imprinted, 240 students of Sungkyunkwan (成均館) raised a group appeal to King Jungjong.

${ }^{44}$ The reason of criminal charge that was the offense of political division, was criticised as not being popularly justified. 
Confucian scholars induced a retroflexion of the royal family under the support of the Hun'gup'a. The reformative politics of moral philosophy conducted by Jo and his colleagues eventually encountered the most hideous purge of the era. The social affair of Kimyo Sahwa (己印士禍, Literati Purge of 1519) eventually affected over 98 Confucian scholars, who were either executed or exiled (Cho 2020: 289-304, Park 1998: 80-104). The key reformists of the Sarimp'a sacrificed were ${ }^{45}$ : Jo Kwangjo (趙光祖, 1482-1520), Gim Sik (金湜, 1482-1520) (Song 2005: 98-103), Gi Jun (奇 遵, 1492-1521), Gim Jeong (金淨, 1486-1521) (Kim 2018: 35-63, Kim 2012: $225-$ 249), Gim Gu (金絿, 1488-1534), Yun Jaim (尹自任, 1488-1519), Bak Sehui (朴世 喜, 1491-1530), and Bak Un (朴薰, 1484-1540) (Annals of King Jungjong Vol. 37, November 16, 1519; Kim 2016: 89-93, Son 2009: 31-53, Park 1998: 80-103). The Sogyŏksŏ and the sacred sites of Taoism were then reinstated when King Jungjong's mother was sick, and they functioned as the royal venue of prayer to heaven for the recuperation of the king's mother: “復設昭格之事, 當慈殿未寧之極, 勢難强執論諫, 不 得已與大臣, 議而處之也。” (Annals of King Jungjong Vol. 47, February 11, 1523). The royal Daoist tradition, even under the continued demand of abolition by the general opinion of all bureaucrats, still lasted until King Seonjo's time of the Imjin War (壬辰倭亂, the Japanese invasions of Korea of 1592-1598) (Kang 2009: 327330).

\section{Conclusion}

The Joseon dynasty witnessed three royal coups through which the throne was replaced under the strategical support of dominant political parties. The Sejo (1455) and Jungjong (1506) coups were led by the Hun'gu faction, while the Injo coup (1623) was conducted by the Seoin (西人, Westerners) of the Sarim faction. When the regal power was weak, the leading party of the royal coups caused four literati purges $(1498,1504,1519$, and 1545) in which Confucian scholars often experienced persecution by their political rivals. For the incident of the Kimyo Sahwa (the literati purge of 1519), the general interpretation often considers the radical issues of sociopolitical reformation of the Sarimp'a, such as the argument of Hyangyak (鄉約, regional autonomism regulation or a self-governing system of community) and the implementation of Hyŏllyanggwa (賢良科, public recruitment system performed by king's personal interview). The critical Sangso (上訴, appeal to king), for the revision of Chongkukgongsin (靖國功臣, the list of recognised contributors for the royal coup; 117 people), further, forfeited the rights and benefits of 76 Hun'gu people.

Those drastic policies were either against the opposite party or for their own political benefits. However, the long-term dispute for the abrogation of Sogyŏksŏ and Daoist rituals was a philosophical and cultural challenge to the royal authority who respected the traditional ruling principles of forefathers (Pŏpcho, 法組). The Sarim scholars did not want their king to keep the cultic teachings of Laozi, the founding

${ }^{45}$ When the Confucian politics settled down well in late sixteenth century Joseon, they were eventually respected as 'the Eight Saints of 1519 Purge.' 
figure of Taoism; rather they constantly promoted and espoused the moral and ethical teachings of Confucius in applying politics and customs. The ideological conflict is well demonstrated through various sacred policies of the royal tradition. The Daoist worship of stars at the official temples of Samch'ŏngjŏn (三淸殿), T'aeilchŏn (太一 殿), Chiksujŏn (直宿殿), and Shibiryojŏn (十一曜殿) opposed the ancestral culture of Jongmyo (宗廟, a Confucian shrine for the deceased kings and queens) and Sajik (社稷, national altars of soil and grain). The literati disliked the status of Sogyŏksŏ as the royal agency of 'heavenly worship.' The Yusaeng (儒生, Confucianists) of Sungkyunkwan (成均館, the national university of the era) also disapproved of the royal behaviour towards the star adoration including Big Dipper and constellations. Thus, the Kimyo Literati Purge of 1519, which was the largest purge of the Joseon dynasty, was the religio-political reaction against the young Confucian scholars. The highest pressure on the Pŏpcho (法組) philosophy of the powerless king burst out by the result of the critical reduction of Chongkukgongsin (靖國功臣), which aroused the political rage of the Hun'gu faction in the royal court of the early 16th century.

\section{Acknowledgements}

This research has been supported by the Korea Foundation (KF) and the Academy of Korean Studies (AKS), Korean government.

Addresses:

David W. Kim,

School of History

Australian National University,

Canberra, ACT, 0200, Australia

R1224, Bugak Hall

College of General Education

Kookmin University

Seoul, 02707, Korea

E-mails: david.kim@anu.edu.au and davidwj_kim@yahoo.co.uk

Tel. : + $61(0) 261253048$ and $+82(0) 201075270878$

\section{References}

Ahn, Dong-gyo (2018) “Kyuam songinsuŭi hangmun'gwa ŭirijŏngshinŭi kuhyŏn”. [Gyuam Song Insu's learning and realization of his fidelity spirit.] Yuhakyŏn'gu 45, 15-25.

Ahn, Dong-Zoon (2004) "Pukpanggye shinhwaŭi shin'gyŏng yuraewa togyoshinang”. [Daoist belief and origin divinity in the Northern Kingdoms.] Togyomunhwayŏn'gu 21, 11-14.

Byun, Kyu-yong (1986) “Taoism and Daoists”. Korea Journal 26, 5, 4-12. 
Ch’a, Chu-hwan (1986) “Kim Shi-sup and Taoism”. Korea Journal 26, 5, 46-54.

Chae, Yun-mi (2019) "Kojŏnsosŏl song togyo hyŏngsanghwaŭi ilgoch'al -kwa ŭl chungshimŭro-”. [A study on the formation of Daoist images of Korean classical novels - in the cases of Imhwa Jongyon and Son Ch'onsa Yongirok.] Kojönmunhakkwa kyoyuk 40, 192-201.

Chang, Jae-cheon (2019) “Chosŏn chungjong huban'gi sŏnggyun'gwan yusaengdŭrŭi hakp'ung munje”. [In the Joseon Dynasty, the latter half of King Jungjong, Sungkyunkwan's academic climate.] Han'guksasanggwa munhwa 97, 29-47.

Cho, Woo-Jin (2020) “Hwasunyuhagŭi chŏn'gaewa nosahakp'aŭi hyŏngsŏng”. [The flow of Hwasun Confucianism and formation of Nohsa School.] Yongbonginmunnonch'ong 56: 289-304.

Chung, Doo Hee (1995) "Kimyosahwawa chogwangjo". [The Literati Purge of 1519 and Cho Kwangjo.] Yoksa Hakbo 146, 87-112.

Fisher, Carney T. (1988) "Smallpox, sales-men, and sectarians: Ming-Mongol relations in the Jiangjing reign (1552-67)". Ming Studies 25, 1-23.

Henshall, Kenneth (2012) A history of Japan: from stone age to superpower. London: Palgrave Macmillan.

Hur, Joon (2020) “Chosŏn chungjongdae sogyŏksŏ kwallyŏn nonŭiŭi sangjingjŏng ŭimi”. [The symbolic meaning of the discussions about Sogyǒksǒ ritual in the reign of king Chungjong.] Sŏktangnonch'ong 78, 231-262.

Hwang, In Gyu (2015) “Han'gung chŏn'gŭndae togyoŭi suyonggwa tobult’ongsŏm -kŏsawa sŭngnyŏ kwallyŏn kirong kŏmt'orŭl chungshimŭro-". [The adoption of Taoism and Daoist and Buddhist consilience in the period of pre-modern Korean society.] Han'guksasangsahak 50, 2-6.

Hwang, Man-ki (2017) "Maae kwŏnyeŭi samkwa nakkangjŏng”. [Maae Kwon Ye's life and Nakgangjeong.] Yongnamhak 60, 179-206.

"Irwŏrobongdo." In Encyclopedia of Korean culture. Last modified January 1, 2021. Available online at $<$ http://encykorea.aks.ac.kr/Contents/Item/E0047296>. Accessed on 04.10.2021.

Jeong, Woo-lak (2005) “Sarimp'a muninŭi yuhyŏnggwa ŭn'guhyŏng(jyaeshwŏp'gya) sarimŭi chŏnjaengch'ehŏm -nammyŏnghakp'aŭi kyŏngurŭl chungshimŭro-”. [A study on the type of Sarim Literati and the war experience of rural member-focsing on the cases of Nammyung School.] Han'guksasanggwa munhwa 28, 7-62.

Jin, Sang-Won (2009) “Anch'ŏgyŏm oksawa chŏngch'ibŏm shinwŏn kwanhaengŭi chŏngch'ak”. [The event of an Cho Kyum and the formalization of the process for redressing grievances in the Chosun era.] Yǒksawa kyŏnggye 73, 36-42.

Ju, Sumi (s.a.) "Cheung pŏrigi”". [Deserting a straw effigy of exorcism.] In Pusanyŏksamunhwadaejŏn. Last modified December 20, 2020. Available online at <http://busan.randculture.net/Contents/ Contents?dataType $=01 \&$ contents_id $=$ GC04201543\&isTreeSpread $=$ Y\&RequestBy $=\%$ ED $\% 95$ \%AD\%EB\%AA\%A9\%EB\%A7\%81\%ED\%81\%AC\&gcode=>. Accessed on 04.10.2021.

Kang, Jiyeon (2009) “Kwaŭi togyoŭi sŏngsoewa yuhakchaŭi kwan'gye-inŭnghwaŭi “chosŏndogyosa”rŭl chungshimŭro-". [The relationship between rise and fall of Gwaui Daoism of Chosun and Confucian scholars: focusing on Yi Neunghwa's.] Tongbanghak 16, 322-327.

Kim, Cheol-woong (2008) “Chosŏnjŏn'giŭi ch'amsŏngch'orye”. [A study on the Chamseong and Daoist ritual in the early Chosun period.] Togyomunhwayŏn'gu 28, 280-286.

Kim, Chng-ho (2016) “Ch'ogisarimp'a shie nat'anan segyesangŭi kyunyŏlgwa taeŭng -muo, kapchasahwagi yubaeshirŭl chungshimŭro-". [The break of the world image and people's response observed in the poems of the early Sarim faction.] Hanmunhangnonjip 43, 89-93. 
Kim, Deok Jin (2007) "Yangsanboŭi kimyosahwa ch'ehŏmgwa soswaewŏn kŏllip" [The Gimyosahwa's Experienc and Sosaewon's Build of Yang, San-Bo.] Yǒksahakyŏn'gu (ku chŏnnamsahak) 30: 83-118.

Kim, Jeong Shin (2020) “Chosŏnjŏn'gi sarim?sarimjŏngch'i yŏn'guŭi chaengjŏmgwa chŏnmang”. [The issue and prospects of research on the Sarim and Sarim politics of the early Joseon period.] Han'guksasangsahak 64 (April), 53-54.

Kim, Kyung-Soo (2018) “Chungjongdae yugyohwa ch'ujin'gwa ch’ungam kimjŏng”. [Confucianised and Chungam Kim Jeong in the reign of King Jungjong.] Yuhakyŏn'gu 44, 48-56.

Kim, Seong-Ryong (2012) "Sahoejŏng ŭisasot'ongŭrosŏŭi munhak". [Literature as a social communication.] Munhakch 'iryoyŏn'gu 25, 155-201.

Kim, Seong Hwan (2003) “Han'gung togwanŭi ch’ŏrhaksasangsajŏng yŏn'gu (2): chungsep'yŏn -kwanbangdogwanŭi sŏngnipkwa ch'ŏlp'ye-”. [A philosophical study on Korean Taoism.] Togyomunhwayŏn'gu 19, 29-72.

Kim, Tang Take (2015) "Chosŏn sŏngjongt'ch'ungjongdae chŏngch'isaŭi ihaewa "sarimp'a"sŏl" [Understanding political history of Songjong-Jungjong's reign in Chosun Dynasty and Sarimp'a.] Yǒksahakyŏn'gu (ku chŏnnamsahak) 58, 1-31.

Kim, Yu Ri (2012) “Ch'ungam kimjŏngt'etchejup'ungt'orokt'erŭi kyoyukchŏng ŭimi” [The educational meaning of 'Jeju Poong-To-Rock' of (Choong Am) Kim Jung.] T'amnamunhwa 40, 225-249.

Lee, Hae-jun (2013) “Shinbibogwiso ronnan'gwa chaep'yŏnggaŭi sŏnggyŏk”. [A study on the criticisms about the appeal for the restoration of Shin and the nature of its reevaluation.] Yuhakyŏn'gu 28, $37-62$.

Lee, Jong-Eun (1986) “Taoism in Korean literature”. Korea Journal 26, 5, 32-34.

Lee, Jong Sung (2010) “Kŭndaewa mannan han'gugŭi togyo -inŭnghwa t'ekchosŏndogyosat'elmŭi kibonipchangŭl chungshimŭro-". [Korean Taoism with modernism- based on Lee Neunghwa's Daoistic history of Joseon.] Tongsŏch'ǒrhakyŏn'gu 58, 315-339.

Lee, Mi-seon (2017) "Chungjong hugung hŭibinhongssiŭi saengaewa haengbo- kimyosahwarŭl chungshimŭro-". [On the life and Aactivities of Lady Hong Hi-bin, the Concubine of King Jungjong in Joseon dynasty - focusing on the political incident Gimyosahwa in 1519.] Yŏsŏnggwa yǒksa 26, 171-197.

Lee, Neunghwa (2000) Chosŏndogyosa. [The Daoistic history of Joseon (1959).] Reprinted by Lee Jongeun, Seoul: Boseongmunhwasa.

Lee, Sang Seong (2010) “Chogwangjo tohagŭi inyŏmjŏng sunjŏngsŏnggwa kamsŏngŭi munje”. [Cho Gwang-jo's pure conscience and grief.] Han'gukch'örhangnonjip 30, 7-36.

Mun, Jae-yun (2009) “Chungjongdae "pŏpcho”ŭi chŏngch'iwŏlliwa chogwangjoŭi kyŏngjangnon”. [Political principle of 'making a model of forefathers' and Jo Kwang-jo's reformation suggestion in Joongjong's ruling period.] Youngnamhak 15, 345-347.

National Museum of Korea (s.a.) “Ch'ŏngja sanggam kuk’wamunŭi chŏpshi”. Last modified December 20, 2020. Available online at <https://www.museum.go.kr/site/main/relic/directorysearch/ view? elicId=4271>. Accessed on 04.10.2021.

Park, Chang Jin (1998) “Chosŏnjo kimyosarimŭi chŏngch'ijŏng wisange kwanhan yŏn'gu; chungjong 10nyŏn (1515) esŏ chungjong 14nyŏn (1519) kimyosahwaijŏnkkaji” [The political place of the Kimyo Literati in the Choson dynasty; from the tenth to the eve of the Kimyo literati purge (the fourteenth year) in Chungjong.] Han'gukchöngch 'ihak'oebo 32 2, 77-79.

Perez, Louis G (1998) The history of Japan. Westport, CT: Greenwood Press. 
Seidel, Anna (1989) Chronicle of Daoist studies in the West 1950-1990. Loyang: Cahiers d'ExtrêmeAsie.

Son, Yoo Kyung (2009) “Mojae kiman'gugŭi shimunhang yŏn'gu -kŭŭi ch'ungjŏngshirŭl chungshimŭro-”. [Kim Ahn-Kook (Mo-Jae)'s perception of Japan.] Hanmun'gojŏnyŏn'gu 19, $31-53$.

Song, Hang-nyong (1986) “A short history of Taoism in Korea”. Korea Journal 26, 5, 13-15.

Song, Woongsup (2001) “Chungjongdae kimyosarimŭi kusŏnggwa ch'ulshinbaegyŏng”. [The composition and original background of the Gimyo sarim at Junjong era.] Han'guksaron 45, 135-192.

Song, Woongsup (2005) "Kimyosahwawa kimyosarimŭi shilgak". [Gimyo literati purge (1519) and political loose of the Gimyo sarim.] Hankuk Hakpo 31, 2, 70-120.

The Academy of Korean Studies (2020) Kimyomyŏnghyŏnŭi kkumgwa ujŏng, kŭrigo kiǒk. [The sages of the 1519 Purge: their ideals, friendship, and memory.] Seongnam: The Academy of Korean Studies Press.

Um, Ki-Young (2011) “Kijaegiit'elmwa chakcha shin'gwanghanŭi chagiinshing -kwa ŭl taesangŭro-”. [Kijaekiyi and the self-awareness of Shin, Kwanghan.] Kososŏryŏn'gu 32, 107-115.

Wagner, Edward Willett (1974) The Literati Purges: political conflict in early Yi Korea. Cambridge: East Asian Research Center, Harvard University Press.

Yang, Eunyong and Samyong Choe (1988) "Pogwŏn'gung sŏllibŭi yŏksajŏng ŭimi”. [The historical meaning of the establishment of Bogwongung.]” In Togyomunhwayŏn'gu [Studies in Daoistic culture] 2, 488-89. Seoul, Korean Association of Daoism Culture.

You, Byung-Rae (2006) “Chosŏnjo sogyŏkchŏnŭi yŏnwŏn'gwa t’ŏe kwanhan koch'al”. [A study on the origin of Joseon's Sogyeokjeon and its site.] Han'guksasanggwa munhwa 32, 130-135.

You, Byung-Rae (2007) “Chosŏnjo samch’ŏngjŏn(dwŏlyŏtjur)ŭi kŏllim paegyŏnggwa t’ŏ[lp]ŭi wich'ie kwanhan koch'al". [The study of the background of the Erection of Sam-Chung-Jeon and the position of its site during the Joseon dynasty.] Han'guksasanggwa munhwa 40, 232-235.

Yun, Chan Won (2003) “Chaech'omunŭi chŏltaeja kwannyŏmŭl t'onghae pon chosŏn ch'oŭi togyosasang". [A religious Daoistic thoughts of early Cho-sun period mirrored in concepts of the absolute in Zhai-jiao.] Togyomunhwayŏn'gu 18, 56-82. 


\section{Appendix 1. The Annals of Joseon Dynasty}

新增東國輿地勝覽 (An Official Book of Geography), edited in 1481, 1486, and 1530.

沈之伯 開國原從功臣錄券 (Certificate of Meritorious Subject Issued to Sim Ji-baek), written in 1397.

太祖康獻大王實錄 The Annals of King Taejo Vol. 4, Taejo Year 2, August 11, 1393.

太祖康獻大王實錄 The Annals of King Taejo Vol. 9, Taejo Year 5, January 10, 1396.

恭靖王實錄 The Annals of King Jeongjong Vol. 6, Jeongjon Year 2, December 18, 1400.

世祖惠莊大王實錄 The Annals of King Sejo Vol. 12, Sejo Year 4, May 12, 1458.

世祖惠莊大王實錄 The Annals of King Sejo Vol. 18, Sejo Year 5, November 28, 1459.

成宗康靖大王實錄 The Annals of King Seongjong Vol. 77, Seongjong Year 8, February 18, 1477.

恭靖王實錄 The Annals of King Jungjong Vol. 1, Jungjong Year 1, October 27, 1506.

恭靖王實錄 The Annals of King Jungjong Vol. 9, Jungjong Year 4, August 28, 1509.

恭靖王實錄 The Annals of King Jungjong Vol. 13, Jungjong Year 6, May 4, 1511.

恭靖王實錄 The Annals of King Jungjong Vol. 13, Jungjong Year 6, May 10, 1511.

恭靖王實錄 The Annals of King Jungjong Vol. 13, Jungjong Year 6, May 12, 1511.

恭靖王實錄 The Annals of King Jungjong Vol. 13, Jungjong Year 6, May 15, 1511.

恭靖王實錄 The Annals of King Jungjong Vol. 21, Jungjong Year 10, February 21, 1515.

恭靖王實錄 The Annals of King Jungjong Vol. 26, Jungjong Year 11, November 21, 1516:

恭靖王實錄 The Annals of King Jungjong Vol. 34, Jungjong Year 13, August 27, 1518.

恭靖王實錄 The Annals of King Jungjong Vol. 34, Jungjong Year 13, August 29, 1518.

恭靖王實錄 The Annals of King Jungjong Vol. 34, Jungjong Year 13, September 3, 1518.

恭靖王實錄 The Annals of King Jungjong Vol. 37, Jungjong Year 14, October 25, 1519.

恭靖王實錄 The Annals of King Jungjong Vol. 37, Jungjong Year 14, November 16, 1519.

恭靖王實錄 The Annals of King Jungjong Vol. 47, Jungjong Year 18, February 11, 1523. 